\title{
From outsider to insider: Opportunity development in foreign market networks
}

\author{
Desirée Blankenburg Holm ${ }^{1}$ - Martin Johanson ${ }^{1,2}$ • \\ Pao T. Kao ${ }^{1}$
}

Published online: 4 June 2015

(C) Springer Science+Business Media New York 2015

\begin{abstract}
By applying the network position concept, we untangle the firm's recognition and exploitation of opportunities during the internationalisation process. We view the transition of network position from outsidership to insidership, in terms of the strength and number of relationships in the foreign market network. Departing from the revised Uppsala model, we argue that opportunity development in the business network consists of recognition and exploitation. Path dependence impacts how a firm exploits opportunity in the network as well as the next opportunity to be recognised, as they are contingent on the network position. Four opportunities are identified from a historical case study of Elekta, a Swedish medical device manufacturer that entered China between 1980 and 2010. We analyse the initial network position of the firm, its opportunity recognition and exploitation, and the network position of the firm in return. Based on the cases we demonstrate that outsidership tends to lead to discovery, while insidership results in creation. The insidership enables direct and indirect relationships, which are involved in the exploitation of the opportunity.
\end{abstract}

Keywords Network position - Opportunity recognition - Opportunity exploitation · Internationalisation $\cdot$ Path dependence $\cdot$ Historical case study $\cdot$ China

Pao T. Kao

pao.kao@fek.uu.se

Desirée Blankenburg Holm

desiree.holm@fek.uu.se

Martin Johanson

martin.johanson@miun.se

1 Department of Business Studies, Uppsala University, Box 513, 75120 Uppsala, Sweden

2 Department of Business, Economics and Law, Mid Sweden University, Holmgatan 10, 851

70 Sundsvall, Sweden 


\section{Introduction}

From theories in international business, we learn that the internationalisation of the firm is underpinned by the recognition of opportunities. The latest Uppsala internationalisation process model (the Uppsala Model) (Johanson and Vahlne 2009; Schweizer et al. 2010) suggests that entrepreneurs recognise opportunities as a reflection of earlier experiences gained from participating international business networks (Hohenthal et al. 2014). It is further argued that firms internationalise through opportunity recognition and exploitation, and during this development (internationalisation) process, they transition from the position of being outsiders to become insiders in the foreign market business network (Johanson and Vahlne 2009; Schweizer et al. 2010). From a business network perspective, the theoretical distinction between outsider and insider is based on the idea that the firm is driven by the potential of combining its resources and competences in a new way with those of others. In the context of internationalisation this means combining resources with those of business partners and creating business relationships that eventually change a firm's position vis-à-vis a network from being peripheral to becoming an insider. This view of the internationalisation process (i.e. going from being an outsider to becoming an insider) motivates our study of distinguishing between different opportunities and the subsequent activities.

Thus, one important distinction we make between opportunities is whether they are recognised in a situation where the firm lacks network-specific business knowledge (i.e. in a stage of being an outsider in relation to the foreign market) or in a situation where the firm has business relationships with other firms in the foreign market network (i.e. as an insider). In the latter case, opportunities will be recognised and exploited within the context of specific business relationships (Johanson and Vahlne 2009). Network knowledge is related to a firm's business network, which consists of the firms with which it is doing business, or trying to do business, and the relationships between firms in this network. The lack of such network knowledge constitutes the liability of outsidership (ibid.). Opportunities recognised from an outsider position are therefore more general in nature in the sense that they can be perceived through market information available to everyone (e.g. economic analyses in business journals or they can appear through indirect relationships such as customers' customers). Another possibility is that an actor in the foreign market makes contact (i.e. a pull mechanism, which is not preceded by an invitation from the outsider firm). The relevance of reflecting the opportunities from an outsider/insider perspective is not just that the opportunities look different depending on the firm's position, but that the ways of exploiting the opportunities also vary, especially in terms of the commitments and the level of embeddedness they cause. The more a recognised opportunity relates to specific business relationships in the network, the more the exploitation of such an opportunity will bond the firm to the network and make it more embedded. Opportunities that are recognised from an insider position are often based on the resources of the focal firm and its business partners, making the relationship parties even more interdependent. So, the more embedded the firm gets, the more specific the subsequent recognised opportunities will be. This reasoning is not, however, free from changes that are beyond the control of the firm or market for that matter. For example, radical changes in laws and regulations can both eliminate and offer new opportunities that are 
independent of preceding opportunities. Altogether, given our view of the internationalisation and approach that focuses on specific opportunities from an outsider/insider position, we believe that our study addresses an unexplored area and therefore contributes to research on internationalisation of the firm.

Our aim with this paper is to answer the following questions: (1) How are opportunities recognised from the position of: (a) being an outsider? (b) being an insider? (2) How are opportunities exploited from the position of: (a) being an outsider? (b) being an insider? To be able to track any path dependencies between these opportunities we also set out to investigate: (3) How these opportunities are related to each other over time.

The remainder of the paper is organized as follows: the next section will present a discussion on the opportunity concept in relation to the Uppsala internationalisation process model in general, which is followed by a more fine grained explanation of the terms we use. Next, we describe the method used before we go into the empirical and analytical section. We discuss our findings and the relevance of exploring opportunity recognition and exploitation during the internationalisation, and finally conclude with our contribution to the research community.

\section{The opportunity concept in the Uppsala internationalisation process model}

This paper departs from the idea that opportunities are mainly recognised and exploited in a network context, and builds on the revisited Uppsala model of internationalisation (Johanson and Vahlne 2009). Firms are assumed to be proactive, which means that opportunity seeking rather than uncertainty reduction drives internationalisation. Opportunity lies in the crosssection of studies on the internationalisation of the firm (Ellis 2011; Santangelo and Meyer 2011; Schweizer et al. 2010), and international new venture creation (Crick and Jones 2000; Chandra et al. 2009; Kontinen and Ojala 2011; McDougall et al. 1994; Knight and Cavusgil; 2004). In comparison to the original model that addresses firms' incremental behaviour on foreign expansion (Johanson and Vahlne 1977), the authors shifted the focus to opportunity, claiming it drives internationalisation. The firm identifies opportunities through business relationships in its network. This is also likely to be the deciding factor in terms of which market the firm chooses to enter. Existing opportunities in foreign markets are important external attention evokers that motivate firms to begin foreign exports (Johanson and Vahlne 1977; Reid 1981; Wiedersheim-Paul et al. 1978). Such opportunities can represent potential growth, e.g. orders of product from a new market (Madhok 1997), or a new venture to exploit the firm's ownership advantages (Dunning 1988; Sharma and Blomstermo 2003).

\section{Defining opportunities}

Opportunity is a desirable but uncertain situation present in foreign markets, which allows firms to benefit from engaging in new cross-border business activities that provide economic value for the firm. It indicates a shift and at least some degree of novelty (Kirzner 1997; Schumpeter 1934). However, doing the same thing over and over again, even if it is profitable, is not an opportunity. Opportunity is something that is assumed to have a positive impact on the firm's economic activity, and since it implies change, Schumpeter's (1934) five loci of change are often viewed as different opportunity types (Shane 2003). The most studied opportunities are either the ones 
which can be labelled arbitrage or those that involve product or process innovation (Mainela et al. 2014). The first type of opportunity refers to buying or selling in the market and is caused by disparity between supply and demand (i.e. market disequilibrium) and manifests as new markets. The second type, innovation, starts with invention and manifests as new resource combinations that can involve the internal resources of the focal firm as well as external resources from business partners.

\section{Defining business networks}

The network perspective views markets as systems of long-term relationships between customers and suppliers. In these relationships, firms adapt and modify their operations, and mutuality and interdependence emerge. This means that each specific firm influences not only its customers and suppliers, but also the whole network, as the relationships are connected (Johanson and Kao 2010). In a dynamic perspective, changes, like product development or innovation, cannot be seen in isolation, as they are not only a firm-internal phenomenon. Thus, in a wider perspective, a business network is a system of economic activities, which are linked to each other (Mattsson and Johanson 1992). When a firm enters a specific country's market, it establishes a position in this market's network, and transitions from being an outsider to holding an insidership position (Johanson and Vahlne 2009). As the firm enters a foreign market it becomes part of the network by developing relationships and commitments to other actors. Through the network, the firm learns about new opportunities and thereby it can expand its networks and its business. The more longterm and robust its relationships are, the stronger firm's position becomes. The strength of the relationships reflects the interdependence in terms of magnitude and symmetry, and the more interdependent the relationship, the more costly it is to terminate, as the interdependence is a result of mutual commitments in terms of investments and adaptations. Consequently, we mean that the strength of the firm's relationships is an important component of its network position.

Network position reflects the trustworthiness and degree of commitment of firms in the relationship network (Schweizer et al. 2010) and is sustained by the relative power dependence existing between network partners (Cook and Emerson 1978; Chetty and Blankenburg Holm 2000; Mattsson and Johanson 1992). Insidership (i.e. an insider position) can enable firms to access exclusive information that may lead to opportunity (Andersson et al. 2006). As such, opportunity is seen as interactively developed when a firm transitions from an outsider to an insider position in the relationship network, through continuous interaction with business partners (Johanson and Vahlne 2006). Opportunity is preceded by information that firms interpret based on prior experience. As they operate in networks, their experience has been accumulated there before determining the manner in which to exploit these opportunities and deal with the risk of uncertainty (Ellis 2011).

\section{Opportunity development in networks}

When a firm develops opportunities, it goes through a process that starts when the firm recognises opportunities (i.e. it finds something new of potential future value) that can be properly absorbed and integrated. Albeit, it is only by exploitation that an opportunity becomes of real economic value (Johanson and Strömsten 2005). Opportunity development 
without exploitation is nothing more than expectations, hopes and dreams, and as the firm is operating in a network, the exploitation has to take place in a network setting.

\section{Opportunity recognition}

The firm's network, the configuration of the same, and the level of relationship embeddedness determine the type of international opportunity that the firm can discover (Johanson and Vahlne 2006; 2009). The opportunity is likely to be found in areas that are already known to the firm (Hilmersson and Jansson 2012), and it will find information leading to the opportunities when equipped with a cognitive readiness (Hohenthal et al. 2003). Therefore, firms may only be able to recognise opportunities that stem from activities in their current operations, leaving little room for them to stumble upon something outside their existing area of knowledge. Mainela et al. (2014) distinguish between opportunity discovery and opportunity creation, and they believe more attention should be paid to opportunity discovery in the internationalisation. Unlike opportunity creation, which emphasises knowledge acquisition through interaction with business partners to enact the opportunity, opportunity discovery results from ignorance about the network, and firms therefore have little influence over it (Alvarez and Barney 2007; Alvarez et al. 2013; Mainela et al. 2014). Unexpected changes or isolated occurrences (i.e. exogenous shock) that lead to opportunity discovery usually have their origins outside the firm's network and cannot be influenced by entrepreneurial activities. Unexpected changes can bring the market to a situation where there is a disparity in the supply and demand that can be exploited by firms (Eckhardt and Shane 2003; Levie and Autio 2011). Firms discovering opportunity through entrepreneurial alertness see existing information from a new angle, and correct past ignorance (Kirzner 1997).

\section{Opportunity exploitation}

Much of the literature focuses on finding, discovering or recognising opportunities. However, from a value point of view, an opportunity is non-existent, if the firm cannot exploit it. Due to the prevalence of experiential knowledge (Eriksson et al. 2000), opportunity development is likely to be a path-dependent process, consisting of both recognition and exploitation (Johanson and Vahlne 2009). Path dependence is described as the "causal relevance of preceding stages in a temporal sequence" (Pierson 2000 , p. 252), meaning that what has happened at an earlier point in time affects the possible outcome of an event (or a sequence of events) occurring at a later point in time (Schreyögg and Sydow 2011; Schreyögg et al. 2011). Through the actions and reactions of the firm and its business partners in the network, the path becomes clear and opportunity is enacted. As firms gain new insights into the foreign market through ongoing interactions, or by experiencing changes that are not anticipated, they may alter existing views of the foreign market and opportunity may emerge (Alvarez et al. 2010). The history of the firm therefore plays a key role in how opportunity is perceived and evaluated (Cattani 2005; Denrell et al. 2003; Shane 2000). In other words, the recognition of opportunity is time and context dependent (Ardichvili et al. 2003; Zander 2007).

While firms gain sustained competitive advantage by exploiting the opportunity available to insiders (Alvarez et al. 2013), path-dependent processes can also result in 
strategy inflexibility that makes them vulnerable. As firms are locked-in to insider positions in relationship networks, the interdependence between partners is high, and the ability to receive new information and form new opportunity becomes limited (Andersson et al. 2007; Schreyögg et al. 2011). In other words, firms may be trapped in the position they strive to achieve through internationalisation and become rigid in reacting to changes occurred in the network. This situation can be particularly challenging for firms entering emerging markets where unexpected changes are common.

Opportunity development in a foreign market's network not only leads to changes for the firm, but also for the network. The firm's network position is strengthened and it takes a step from outsidership to insidership, which, in turn, is likely to influence where and how the next opportunities are recognised. The opportunity development contributes to either expanding the firm's network or strengthening the firm's existing network in the foreign market, thus changing the network. Expansion is mainly happening when opportunities enable firms to terminate and replace existing relationships or add new relationships in the network. Strengthening of the network occurs when business relationships are deepened in terms of higher adaptability and commitment. Although this can make it difficult for a firm to exploit new opportunities outside its existing business relationships, as it would involve excessive changes in the already adapted business network, which sometimes forces the firm to balance sunk cost against potential gain.

\section{Outsider and insider opportunities}

In this study, we propose a conceptual framework to explain the opportunity development that occurs when firms move from outsidership to insidership (Fig. 1). Opportunity development is thus a process consisting of two phases, where the first recognition is contingent on the network position of the firm being somewhere on a continuum from complete outsider to complete insider. The closer a firm is to being an outsider, the more likely it is that opportunities are discovered or occur surprisingly through the firm's indirect relationships. The reason is that from an outsidership position, the firm does not have a lot of direct relationships with firms in the foreign market, and consequently the flow of actual business information from the market to the firm is limited. Often the information needs to pass several actors as it moves between the market and the firm. This may hamper the quality and validity of the information reaching the firm. An outsidership position therefore contributes to the tendency for opportunities to be mediated through other firms.

As soon as the firm begins to develop direct relationships, it at the same time starts to position itself as an insider in the network. Insidership influences opportunity recognition in two ways. First, in direct relationships, firms interact and solve problems together; that is, they not only exchange information but also create and share knowledge, which is sometimes tacit. In parallel, the insidership increases the volume of information flowing to the firm about what is happening beyond the direct relationships. As the volume is big, the firm can compare the content and the quality, making the information more reliable. The number of sources of information, the quality of the knowledge and closeness of the direct relationships contribute to the tendency for opportunities to be created as a result of the interaction, rather than discovered. 


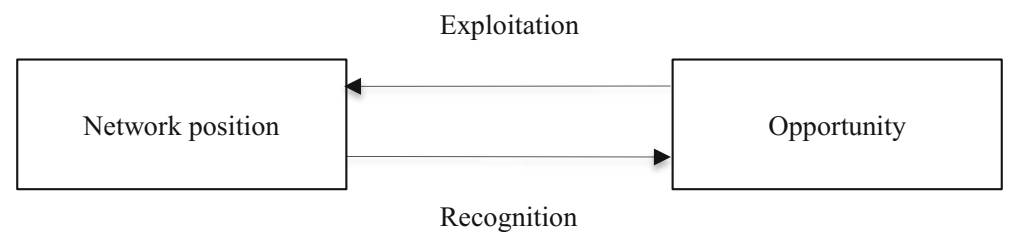

Fig. 1 The conceptual model of opportunity development in foreign market networks

The other side of opportunity development-exploitation has to take place somewhere. Since the firm is part of a network, relationships with customers and suppliers that reflect the network position of the firm make up the arena for where the opportunities are exploited. Products are sold to other firms in the network and technology is used to produce the products. Thereby exploitation of opportunities also influences the firm's network position, leading the firm's network to either weaken or strengthen, and expand or shrink. A network is strengthened when the interdependence and mutual commitment in the relationships increase, making it less likely that the firm will leave the network. Through opportunity development, the firm can also expand its network by adding business relationships in the foreign market's network, which results in more business, but also access to more information, as the number of counterparts grows.

\section{Method}

\section{Research design}

This study is based on a single historical case, and the reasons why we chose this approach are manifold. Firstly, as a single case, we can focus on the complexity of the firm's internationalisation and have an in-depth examination of critical opportunities during the process (Dubois and Gadde 2002; Piekkari and Welch 2011). Secondly, as a historical case, we are able to study different phases of the firm's internationalisation, as well as the surrounding network and events that might play an important role in shaping the opportunity (Burgelman 2011; Jones and Khanna 2006; Pettigrew et al. 2001). Lastly, the theoretical approach to the opportunity development underscores path dependence, and by utilising a single historical case, the temporality element that is essential to the process can be preserved (Rowlinson et al. 2014; Welch and Paavilainen-Mäntymäki 2014).

\section{Research object}

We purposely chose to study Elekta, a Swedish medical device manufacturer, as a single historical case to investigate how firms develop opportunities over time in the foreign market. Founded in 1972 by Professor Lars Leksell at the Neurosurgery Department of the Karolinska Institute in Stockholm, Elekta is a world leading medical equipment group, focused on developing non-invasive or minimally invasive technology for cancer and brain disorder treatment. Its main products include the Leksell 
Stereotactic System, Gamma Knife and Linear Accelerator (Linac). Despite its rapid international expansion throughout the 1980s, Elekta remained as a small, young entrepreneurial firm (Levin 2006). China has grown to play a significant role in the internationalisation of Elekta over time. Elekta began exports to China in 1982, and China was also one of the first few markets where Elekta sold the Gamma Knife in the early 1990s. Since 2000, Elekta has established a production subsidiary in China and grown to become the market leader in China's Linac segment. Currently, China is Elekta's second largest market globally and the third largest operation base in terms of number of employees (Elekta 2014).

\section{Data collection}

To uncover and trace the historical events over time, we utilised both archival and interview data to reconstruct Elekta's history of market entry and expansion in China between 1980 and 2010 (Easton 1995; Mintzberg 1977; Kipping et al. 2014). In contrast to studies that treat history as background information, or use it for the purpose of triangulation (Eisenhardt 1989; Yin 2003), the use of archival data is instrumental in this study. It not only allows us to cover a much longer period of time with sufficient details, such that processes of change can emerge (Welch 2000), but also serves to preserve the history of the actors, activities and events (Decker 2013). Following Farjoun's (2002) suggestions, archival data was sourced from company archives, annual reports, meeting notes, industry and trade journals, governmental announcements found in public records and policy documents, laws and regulations, as well as Chinese and foreign media. The archival data collected in this study falls into two categories: the first is for establishing Elekta's internationalisation to and within China, and the second refers to the critical events that took place in China's medical device industry. We also assessed the quality of archival data by examining the authenticity, credibility, representativeness and meaning (Welch 2000).

Moreover, we collected interview data to strengthen the interactive and contemporary aspect of the study (Welch 2000) and to supply the necessary story behind the history and supplement the lack of emotion in the archival data (Piekkari et al. 2010). Six face-to-face, semi-structured interviews were conducted between 2010 and 2013 with key and supporting informants from among Elekta's Chinese subsidiaries, Chinese customers, and its Swedish headquarters (Appendix). The interview questions focus on the strategic decisions behind Elekta's on-going market entry and expansion in China (e.g. Who was the person initiating the decision? What kind of evaluation had been done before the decision?). The key informant approach is deemed suitable as Chinese business practices strongly emphasise hierarchy (Tan and Nojonen 2011), and strategic information therefore tends to be controlled by a few decision makers who normally occupy upper management positions (Coviello 2006; Ellis 2011). These interviews lasted between 40 and $180 \mathrm{~min}$, and were conducted mainly in informants' offices or places that were convenient for the informants. They were conducted in English or Chinese, digitally recorded and later transcribed. The interview added a real-time dimension to this study, which enabled the research time to coincide with case time (Blazejewski 2011). 


\section{Coding and analysis}

Interviews and archival data were coded with King's (2004) template coding method to enable flexibility during the coding process, as well as reflexivity for research themes to emerge. We followed Langley's (1999) suggestions to process the data with various analyses. Firstly, we applied the narrative method to chronologically explain the market of the case firm and show linkages among activities, actors and events (Pettigrew 1990).

From the narrative, we identified four critical opportunities, which make up the subcases that are analysed. We perceived four opportunities as critical in the internationalisation of Elekta. They include how Elekta:

1. Began to export medical devices to Chinese Hospitals;

2. Found a production subsidiary and global sourcing centre;

3. Acquired Beijing Medical Equipment Institute (BMEI) and developed a new Linac (Elekta Compact); and

4. Developed a distributor network across China and began to sell the Linac and Gamma Knife in China's smaller interior cities.

These four critical opportunities correspond to several of Schumpeter's loci of change (1934): finding market and customers, organizing production in a new way, re-organizing the firm, developing new products and finding new suppliers and new ways of organizing sourcing (Table 1). In the following section, we present the four opportunity cases and analyse how Elekta recognised and exploited them. Furthermore, we map Elekta's network in order to present the relationships between Elekta and other local actors and thereby also visualise Elekta's network position.

\section{Case empirics and analysis}

\section{Opportunity 1}

\section{Network position and opportunity recognition}

Elekta has no previous contact in China when the country initiated its Open Door Policy in 1979, which manifests an opportunity characterised as an unexpected change. Elekta comes to recognise the demand from Chinese hospitals for upgrading medical technology, and they receive an unsolicited order for the Leksell Stereotactic System in 1982. Elekta is ignorant about the development in China and has no relationships with the customers. Their receipt of this order is serendipitous and not the result of a deliberate strategy or strong position in the Chinese network.

Elekta becomes aware of the interest from Chinese hospitals for its Gamma Knife a few years later. Not only is the Gamma Knife the first of its kind in the market at this time, but also Elekta is the only producer in the world. In 1991, a Chinese hospital sends a delegation to visit Elekta in Sweden indicating the intention to purchase a Gamma Knife. In the next 3 years, Elekta receives orders from China for 13 units of the Gamma Knife. At the time, there are only 65 existing units of the Gamma Knife 


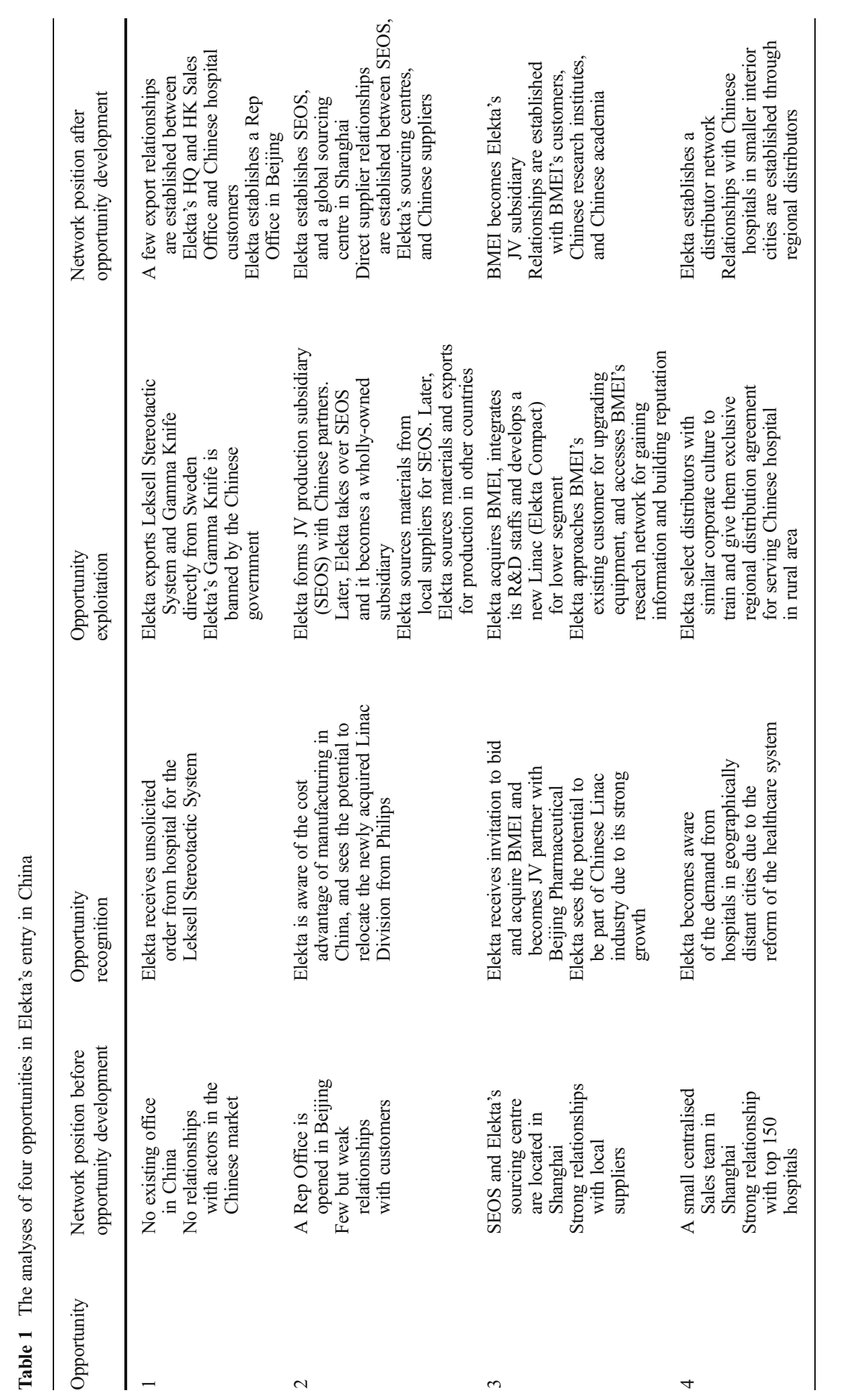


worldwide, and roughly one fifth of them have been sold to China. Elekta estimates potential sales of more than 100 units of the Gamma Knife in China, and believes China "will be a large market for its neurosurgery equipment as the country's medical facilities upgrade their technological capabilities" (South China Morning Post 1994).

It can be argued that Elekta recognises the opportunities through discovering the demand from the Chinese hospital for its advanced medical device after the changes of the policy and regulation in China. Elekta has little knowledge about the Chinese market and no existing relationships with these customers prior to this discovery.

\section{Opportunity exploitation and network position}

After receiving unsolicited orders for the Leksell Stereotactic System from Chinese hospitals, Elekta exports the system directly from Sweden to the customers in China. While there is certainly interest in Elekta's device from China (Du et al. 1995; Meng 1990), sales of the Leksell Stereotactic System are not significant. In the beginning of the 1980s, there are only 200 neurosurgeons who would use the stereotactic system in all of China (Xu 1990), so the demand for the stereotactic system is limited. Additionally, there are competing stereotactic systems available in the market, including a stereotactic system invented in China (Wu et al. 2005; Xu et al. 1978). Elekta's Leksell Stereotactic System may present certain authenticity, but the stereotactic system as a whole is a mature product and there is little difference in designs between competitors.

When Chinese hospitals begin to show interest in Elekta's Gamma Knife, Elekta is being recognised as a player for more than the company that sells the stereotactic system. Elekta establishes a sales office in Hong Kong in order to look after business in the Asia Pacific region. The first unit is sold to Shanghai's Hua Shan Hospital in 1992, and 12 additional units are ordered by other institutions in the following 3 years. These Gamma Knives are exported directly from Sweden. Seeing the potential growth of the export, Elekta establishes a Representative Office in Beijing.

Elekta's optimism in making China a large market is shattered when the Ministry of Health $(\mathrm{MOH})$ and other governmental agencies in 1995 issue a prohibition to stop hospitals from making purchases of Elekta's Gamma Knife. This is an attempt to control Chinese hospital's insatiable appetite for buying expensive medical devices. Various levels of government own Chinese hospitals and they depend on governmental funding to purchase medical devices. Later, a new regulation requires hospitals to obtain permission from the $\mathrm{MOH}$ prior to making any purchase of the Gamma Knife and other imported, large and expensive medical devices. From 1996 to 2008, Elekta is not able to sell any more units of the Gamma Knife to China. Therefore, the initial step towards the Chinese market network is wiped out and instead of making progress towards becoming an insider Elekta finds itself still being an outsider.

Another setback for Elekta and the sales of the Gamma Knife is when the Chinesemade version of the Gamma Knife (known as the Gyro Knife) appears in the market in late 1994 (SP LAB 2011). The Gyro Knife is the result of reverse engineering done on the imported Gamma Knife by a group of Chinese and represented a simplified version of this medical device (Outlook Weekly 2009). Elekta's Gamma Knife used 201 cobalt gamma rays, while the Gyro Knife used only 30 (Zhang 2009). With a cost one tenth of the Gamma Knife, the Gyro Knife was especially attractive to cash-strapped Chinese hospitals. Since it is produced locally, there is also no need to obtain machine 


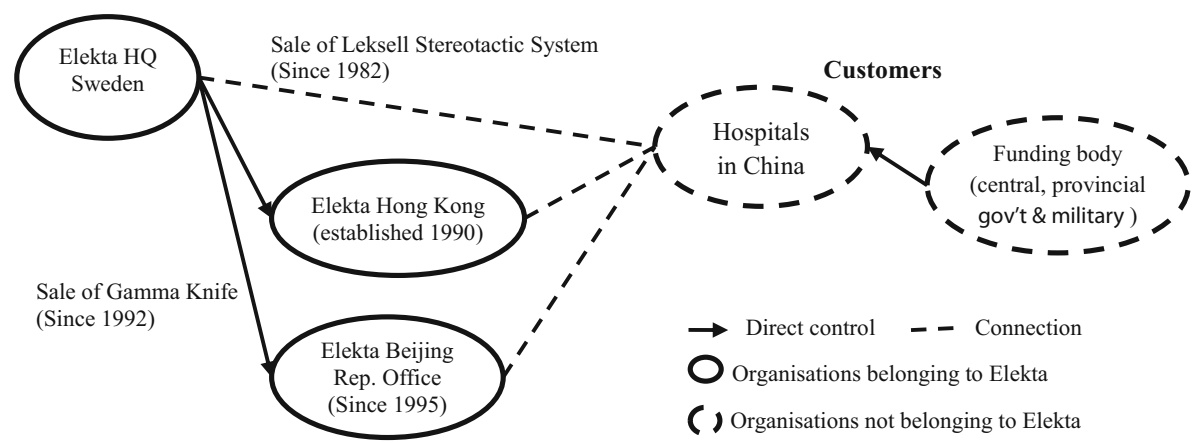

Fig. 2 Elekta's network map in opportunity 1

importation permission from the central government. Sales of the Gyro Knife grew quickly during Elekta's absence from the market. By 2010, the Gyro Knife was estimated to make up $90 \%$ of the 220 units installed in Chinese hospitals (SP LAB 2011).

Throughout this opportunity development, both the recognition and exploitation are handled either by the Swedish Headquarters or Hong Kong Sales Office, which experience very little modification to the existing sales process. The products are also directly exported from Sweden and require very minimum adaptation to the host market. The decline of interest, increasing competition, and particularly changes of regulations in a later stage stop Elekta's further exploitation of the opportunities. Elekta has a limited network in China's medical device industry (Fig. 2). Since all the export products are manufactured in Sweden, Elekta has no supplier in China. Both Elekta's headquarters and Hong Kong Sales Office are located outside China, and Elekta's direct presence in China has only begun in late 1995. The relationships with the Chinese customers are less committed due to the nature of export. As such, Elekta could be considered an outsider of the Chinese medical device industry.

\section{Opportunity 2}

\section{Network position and opportunity recognition}

In 1997 Elekta acquires Philips' Radiation Therapy (RT) Division and its main product Linea Accelerator (Linac). Elekta soon becomes aware that the production cost for the special patient bed belonging to this product is too high to be competitive. Elekta starts to reconfigure Linac's production chain and through Elekta's Representative Office in Beijing, it recognises the opportunity to move the production of Linac's patient bed from The Netherlands to Shanghai. At this time, Elekta is still in a position of being outside the Chinese network and has great uncertainty about investing in China due to sales of the Gamma Knife to China remaining restricted. As the opportunity to cheaply manufacture the patient bed is being recognised through the office in Beijing, it can be categorised as created more than as a discovery.

Furthermore, Elekta's production of patient beds in China enables it to work with local suppliers. Till this point, Elekta had only contracted local suppliers to produce simple devices and equipment to be integrated into the patient bed, but they now see the opportunity to engage Chinese suppliers on behalf of Elekta's production units 
elsewhere in the world. Elekta discovers the potential to include these local suppliers into its global supply chain.

\section{Opportunity exploitation and network position}

For the purpose of starting up production of the patient bed, Elekta sets up an office in Shanghai and identifies two former state-owned electronics manufacturers (Shanghai Jinling and Shanghai Huelong). It enters a joint venture (JV) agreement with these two manufactures to establish Shanghai Elekta Oncology Systems (SEOS) in 2000. Since the Open Door Policy, China has permitted foreign direct investment (FDI), and there is no particular regulation required for foreign medical device manufacturers to form a JV. But Elekta considers it may be necessary to obtain experience from the local firms, since it knows little about the local suppliers. While Elekta's decision to relocate the manufacture of Linac's patient bed to China is assumed to increase cost competitiveness, it also argued the move would "strengthen Elekta's overall presence in China" (Interview with the Chairman of the Board of Directors, Elekta AB, 2013).

According to the JV agreement, Elekta holds a $60 \%$ share of the business unit and is responsible for providing technical knowledge for production of the product, which would be exported and sold internationally as part of the Linac. Two Chinese partners control the remaining $40 \%$ and are responsible for factory management and contracting local suppliers. Elekta soon realises that its partners are more focused on making sure Elekta does not cheat on them, than supervising and ensuring smooth operations in the factory. Therefore, Elekta decides to buy out its JV partners and to make SEOS a wholly owned subsidiary. Additionally, Elekta brings in professional management and quality control and gradually improves SEOS' operational efficiency. In 2005, SEOS is fully integrated with Elekta's global manufacturing network and becomes the sole production base for the Elekta Linac patient bed worldwide.

Elekta decides to expand its sourcing activities in China. After China's WTO entry, it becomes much easier to import and export goods across the border. Elekta begins by sourcing simple materials, such as metallic tubing, and gradually expands to more sophisticated modules and systems. As the volume increases, Elekta decides to

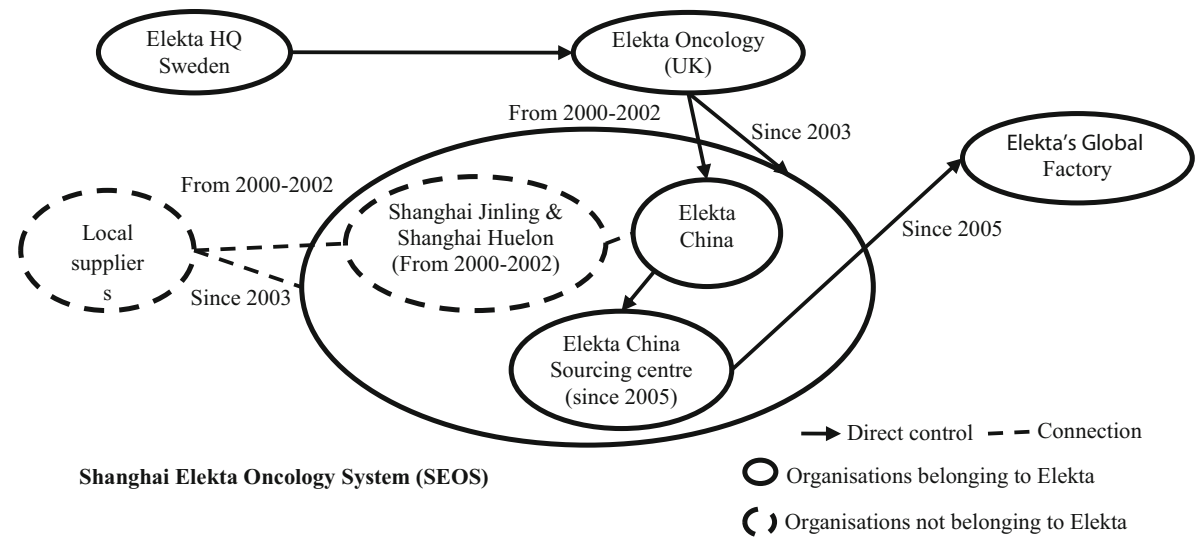

Fig. 3 Elekta's network map in opportunity 2 
establish a global sourcing centre, in order to source systems for its global factories. The exploitation of these opportunities enables a direct connection between Elekta and its local suppliers due to its sourcing operations (Fig. 3), and this change has further taken the company from an outsider position towards that of an insider.

\section{Opportunity 3}

\section{Network position and opportunity recognition}

By 2006, Elekta has gained a strong position in the network. On the one hand, Elekta's China subsidiary has established strong relationships with local suppliers as it continues sourcing materials for its global productions, but it also forms connections with local hospitals. The investment in production of the Linac's patient bed in China demonstrates Elekta's long-term strategy through which Elekta is gaining a better understanding of the competence of the Chinese manufacturing industry.

On the other hand, the closer connection with local suppliers and an insider network position facilitates Elekta's understanding of the current market conditions. Elekta perceives that the market is growing, as Medical Physicists have doubled in number compared to a decade ago, and installations of the Linac triple. As the economy has grown, people have become more aware of the threat of cancer, and most importantly, are beginning to have the resources needed to seek treatment. Elekta believes there is room for the Linac industry to continue to grow, as China has only 0.7 Linac units of per million people, which is still behind the two to three units per million recommended by the World Health Organisation (WHO). Additionally, the cost advantage it has achieved through this production, has allowed it to make headway in competition with both international and domestic Linac producers.

Elekta needs to further strengthen its position in the Chinese Linac industry. The customer base for the Linac is rather stable, and there are only three international and two domestic Linac producers competing in the market. The international producers (i.e. Elekta, Varian, and Siemens) focus on the premium to medium segment of the market, while the lower-end segment is occupied by two Chinese producers, including Beijing Medical Equipment Institute (BMEI) owned by Beijing Pharmaceutical Co., and Shandong Xinhua Pharmaceutical Co. They are run like traditional state-owned production units; even though they both possess their own technology through collaboration with local research institutes and hold 80 to $90 \%$ of the lower-end segment of the market, they lack efficiency and are losing money.

The fact that Elekta both produces and serves so many customers means that when BMEI is put up for sale in 2005, the Chinese government informs Elekta about their intention to sell off the unprofitable state-owned enterprise. Thanks to their positions in the market, Elekta, Varian and Siemens are all invited to submit a proposal to acquire an $80 \%$ share of BMEI and become Beijing Pharmaceutical's JV partner. Despite its negative JV experience in the past, and the fact that acquisition also means significant financial and technological investment, Elekta sees investing in BMEI as a way to become part of the 
Chinese Linac industry. Owning BMEI would enable Elekta to transform its import-led business to one built completely on local manufacturing. Given the size of the Chinese market, Elekta argues it "really had to be part of the (local) establishment" (Interview with the Chairmen of the Board of Directors, Elekta $A B, 2013)$. Elekta fights off the other two international Linac producers and wins the bid to acquire BMEI in 2006.

\section{Network position and opportunity exploitation}

Elekta immediately relocates the production of some Linac components to BMEI. With assistance from SEOS, BMEI is quickly turned around and managed with efficiency and quality in mind. Exploiting BMEI's factory capacity is a cheaper and faster solution than building a new manufacturing facility. BMEI's research capability is also quickly integrated with Elekta's Oncology R\&D lab in the UK, and a new Linac named the Elekta Compact is invented in 2008. The Elekta Compact is positioned as a cost-effective treatment system that satisfies fundamental radiation therapy requirements for start-up facilities. It targets the medium to lower segment of the market and fills the gap in Elekta's product portfolio. The Elekta Compact gains approval from SFDA in 2009, and more than 100 units are installed in Chinese hospitals over the next few years. Elekta Compact also proves to be popular in other emerging markets such as India and Mexico, and even attracts customers in developed markets, as many European radiation therapy clinics find the Elekta Compact to be a more affordable option following the financial crisis and tightening of medical budgets.

By acquiring BMEI, Elekta becomes further integrated into China's Linac network in terms of the direct relationships they establish and the actors they connect with (Fig. 4). BMEI's relationships not only enable Elekta to access production facilities and technology, but also through these, Elekta develops relationships with new customers, and Chinese research and academic institutions.

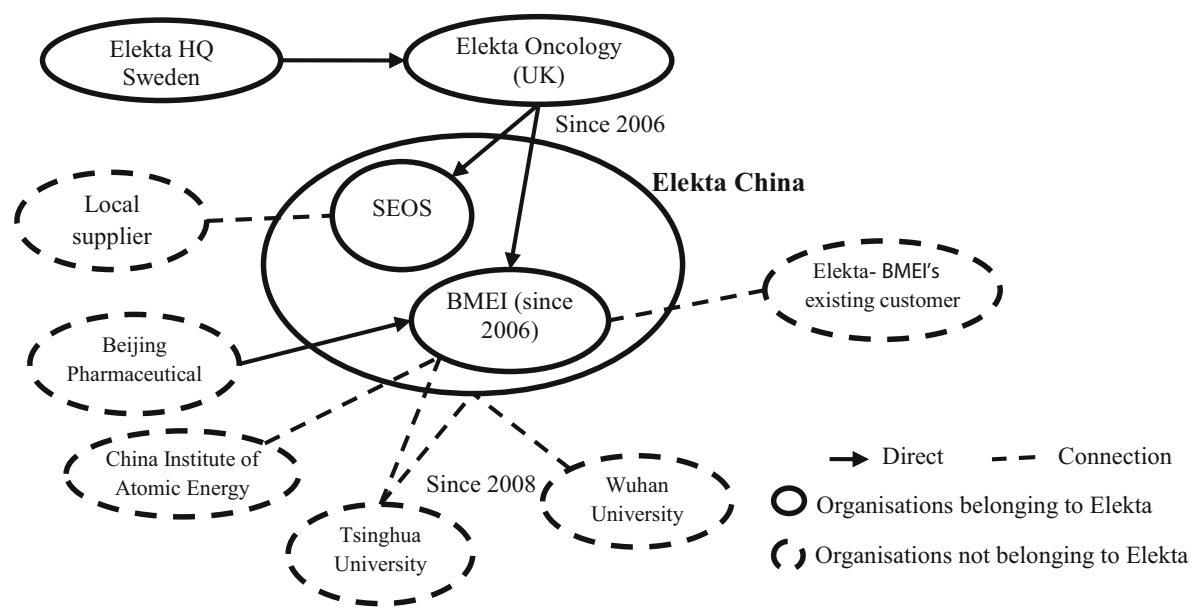

Fig. 4 Elekta's network map in opportunity 3 
This acquisition also enables Elekta to access BMEI's existing customers, many of who are in the process of upgrading their Linac units. Some of these hospitals still use Elekta's basic Linac (e.g. the Elekta Compact), while others are persuaded to upgrade to Elekta's premium products. Elekta also develops relationships with research institutes and academia through BMEI's existing relationships. Many of BMEI's researchers come from renowned research institutes and possess connections with other academic institutions and government officials. Tapping into these research and government networks provides Elekta better access to information about the Linac industry.

To further enhance this network, Elekta begins to provide scholarships to prestigious universities with medical physicist programs, such as Tsinghua University and Wuhan University. These activities contribute to a positive reputation, as Elekta is seen as a partner of the growing Chinese medical device industry. After this acquisition, Elekta's employee numbers in China grow to 336, representing one eighth of the global workforce, and making the subsidiary the third largest business unit. Elekta and BMEI together control more than $42 \%$ of the market for Linacs in China.

\section{Opportunity 4}

\section{Network position and opportunity recognition}

Elekta relies on a small and centralised sales team to sell the Linac. This team is mainly based in Shanghai with a few people in Beijing and Guangzhou to handle the marketing and sales activities. This team works with hospitals to assist them to purchase the Gamma Knife or Linac. The purchasing process normally takes 12 to 24 months to complete, and this gives Elekta multiple chances to interact with these hospitals and decision makers, which means that the interaction is intensive and the relationships formed with the customers are rather strong. Elekta's sales people are involved from the initial planning process, and their advice is considered to be valuable for the decision makers as for many of them, a Linac or even a Gamma Knife is one of the most expensive purchase investment decisions they ever make in their career. These machines are meant to operate for ten to fifteen years, therefore it is important to choose a good quality product as well as a supplier with a good reputation and service attitude.

Over the years, this sales team serves and maintain good relationships with China's top 150 hospitals. These prestigious hospitals are financially independent and seldom require government funding to support their purchase of expensive medical devices. They are also located relatively close together in the coastal areas, making them easily managed by the team. Occasionally, Elekta also works with local distributors on an adhoc basis. If a distributor has a customer, Elekta works with them on the basis of a onetime distribution agreement and prefers to develop direct relationships with the customers. Even after the acquisition of BMEI, the sales team still controls most of the sales and relationship building activities.

China introduces a Healthcare System reform bill in 2010, and the government begins to distribute medical resources to second- and third-tier hospitals located in smaller interior cities with the intention to bring affordable healthcare to more people across a wider number of regions. Previously, only hospitals located in coastal regions 
were able to afford the expensive machines, but this reform means that hospitals in China's interior regions can also purchase premium medical devices. Elekta decides to expand the market for the Gamma Knife and Linac in these interior cities, but its centralised sales model cannot cope with this expansion. "In the past, Elekta might only need to contact the top 150 hospitals and it could cover all the potential. But in the next five years, it can be 350 hospitals, and how can we have the coverage for the remaining 200 hospitals?" (Interview with the CEO, Elekta China, 2011).

\section{Network position and opportunity exploitation}

With the enlargement of the market and the geographically dispersed base of customers after the healthcare reform, serving hospitals in China's interior cities is extremely difficult with the existing team and resources. Elekta realises it would take too long to build its own sales team to cover this vast territory, and thus it begins searching for regional distributors for collaboration. From previous experience working with regional distributors, Elekta knows that some of them share similar goals and organisational culture. Elekta looks for distributors that put emphasis on long-term relationship development. During the period between 2011 and 2012, Elekta identifies two regional distributors through its existing network and begins working with them through exclusive regional distribution agreements. Elekta trains the regional distributors, which are supposed to contact second- and third-tier hospitals. When a hospital decides to purchase a Linac or a Gamma Knife, both Elekta and the distributors provide assistance in the purchasing process.

Elekta continually serves the top 150 hospitals and maintains the relationship directly with them, but the relationships with regional distributors enables Elekta to reach hospitals in China's more remote cities without expanding its existing organisation. Elekta's relationships with the second- and third-tier hospitals are indirect during the purchasing, but are transformed to direct relationships once the Linac or Gamma Knife is installed. Elekta strengthens its position in the Chinese network where it can sell its products (Fig. 5). Elekta maintains direct control of the installation, service and maintenance, as the distributor might not have enough capability, but Elekta also believes these relationships provide important information.

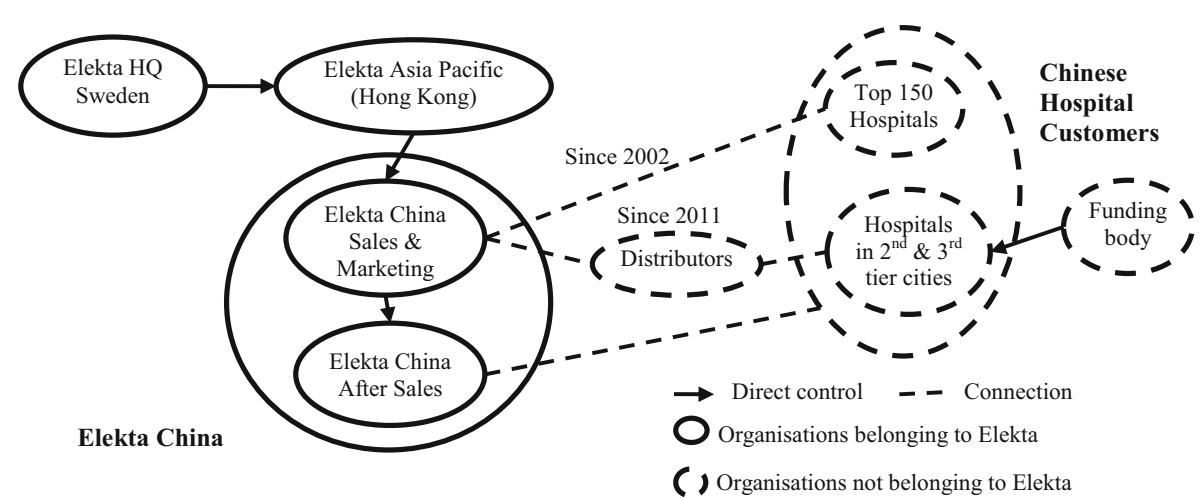

Fig. 5 Elekta's network map in opportunity 4 


\section{Discussion}

The four opportunities present the internationalisation of Elekta in light of opportunity recognition and exploitation. The firm's network position changes over time as a consequence of opportunity exploitation, which in turn makes the firm recognise new opportunities. The opportunities represent different developments. The first is characterised by a weak network position, which is manifested in ignorance about the business network in China. Although Elekta's knowledge about the Chinese market is limited, Elekta discovers an opportunity to export when Chinese hospitals initiate contact. From an outsider position Elekta has limited relationships to firms in the Chinese network. These are only more or less distant indirect relationships with only limited commitments, and the opportunities being recognised do not include combinations of their own and others' resources. By doing this, Elekta takes the first step in gaining a position with few and weak relationships in the network. The exploitation of the opportunity mainly leads to an expansion of the firm's network. This observation indicates that the weaker the network position (i.e. when the firm holds an outsidership position), the more likely it is that opportunities are recognized through discovery rather than creation. A second conclusion that we can draw from this opportunity is that, the more the opportunity recognized is made through discovery, the more the change of the network position is characterized by expanding the firm's network, rather than strengthening its existing network.

The second opportunity starts from Elekta holding a somewhat stronger network position. The relationships are weak, but the network mediates information about the opportunity exploiting low labour costs. As such, Elekta acts on this and forms a joint venture, which is an opportunity development that is closer to creation than discovery, even if Elekta still is rather ignorant about the network. The partners in the network are initially important for the exploitation. The opportunity exploitation results in Elekta strengthening its network position. At the same time, this opportunity also results in Elekta developing new relationships to various suppliers. Consequently, Elekta's network also expands.

The third opportunity contains two elements: acquisition of BMEI and development of a new Linac. Here Elekta's network position is a prerequisite. The position gives the impression that Elekta is a legitimate firm with a long-term view on China, which is necessary in order to come in contention as a future owner of BMEI. The network position, which is strengthened through the acquisition, also provides Elekta with the information that there is a need to update and to develop a new Linac. These opportunities are characterised as creations rather than discovery. Elekta has the knowledge and the opportunities are not recognised through surprise or luck. Instead both recognising and exploiting the opportunity involve several actors and extensive interactions and communications. The acquisition of BMEI and development of the Linac primarily result in a stronger network position, but the exploitation also means that Elekta's network of relationships is expanded. Based on the second and third opportunities, we propose two conclusions. The first is that the more the opportunity is created, the more the exploitation involves both the firm's direct and indirect relationships. Moreover, we argue that the more the opportunity exploitation is a result of creation of opportunities, the more it tends to lead to both strengthening and expansion of the firm's network position. 
The fourth opportunity development starts from a strong insidership position, but in this case, the development is not initiated from other firms or organisations. Instead, it is a proactive strategy, which means that Elekta and the new distributors create an opportunity together. Thereby Elekta deliberately uses its network position in order to reach and exploit opportunity beyond its direct relationships. The weak relationships that are developed with both the distributors and the hospitals indicate a network expansion.

Consequently, when the firm has an insidership position, the opportunities are created rather than discovered. Exploitation of opportunities in a network where the firm has a strong insidership position requires coordination of several of the firm's relationships. In line with this, the stronger the firm's insidership position in the network, the more the strengthening requires expansion and vice versa. Thus, these two results of the exploitation are difficult to separate, when the firm has an insidership position.

The revised Uppsala model (Johanson and Vahlne 2009) argues that in terms of the development of opportunity, past literature exaggerates the role of serendipity leading to discovery, and neglects exploitation of opportunities. These cases demonstrate that by not delimiting opportunity to recognition, and by following the assumption that firm operates in networks, path dependence is a consequence. We observe that our understanding of opportunity development increases if we apply a network perspective on internationalisation. Opportunity discovery is likely to be essential in a process where knowledge and relationships in the foreign market are absent. When a position in the foreign market network is developing, the boundaries for which opportunities are recognised can be observed, and it is evident in the three latter cases. Opportunities are recognised and thus mediated by the network. Instead, Elekta involves its relationships when exploiting the opportunities by coordinating and integrating network elements. The cases also show that exploitation tends to lead to a stronger insidership position. In some of the cases, this mainly implies expanding the network by adding more relationships, while in other cases strengthening the existing relationships is the main driver in the process of achieving an insidership position.

\section{Conclusion}

In this study, we set out to understand how network position (i.e. being an outsider vs. an insider) affects the firm's ability to recognise and exploit opportunities in the internationalisation. Additionally, we also look at how opportunities are exploited by the firm relate to each other over time. Drawing theoretical foundation from the latest Uppsala Model (Johanson and Vahlne 2009), we propose a conceptual model to explain the opportunity development in the network. We argue that opportunity development in the network consists of recognition and exploitation; the latter is done very much by building business relationships in the foreign market, and thus developing a network position and becoming an insider. Further, it can therefore be said that network position makes up the foundation for which opportunity the firm recognises, and that there is a path dependence between opportunity recognition and exploitation. A firm can only exploit the opportunities that are being recognised, and it can only recognise further 
opportunities from what it has exploited. Put differently, the firm can only recognise opportunities that are visible from its current network position, which in turn is a result of its exploited opportunities.

Our study contributes to the knowledge of the internationalisation by demonstrating the relatedness between opportunity recognition and exploitation over time (i.e. the path dependence). By applying the network position concept, we illustrate the prerequisite for firms to recognise and exploit opportunities during different phases of the internationalisation, in the transition from outsidership to insidership.

We also see there is good potential for future studies to tackle the dominance of the path dependence in opportunity development, in particularly to its potential negative impact (i.e. the lock-in process). Path dependence is said to be an "unavoidable byproduct of a beneficial relationship" (Johanson and Vahlne 2009, p. 1418). Yet, when a firm is locked-in because of the interdependence created in the past (interpreted as path dependence), the variety of opportunities it potentially may develop can be dramatically reduced. In other words, firms lose flexibility and become rigid in their strategy deployment. For firms operating in turbulent markets (e.g. typical of emerging markets), lack of flexibility may be threatening to their long-term survival. Once promising opportunities may disappear unexpectedly, and firms may face difficulties to break out of the locked-in position. Further research may investigate firms experiencing lock-in as insider of a network and how it may affect the opportunity development in the internationalisation.

\section{Appendix}

Table 2 List of the Interviews with key informant

\begin{tabular}{lll}
\hline No & Interview date and time & Informant position and company \\
\hline 1 & October 22, 2010/10:30-12:00 & CEO, Elekta (China) \\
2 & March 11, 2011/11:15-13:00 & CEO, Elekta (China) \\
3 & March 18, 2011/several & Medical Doctor, Guangdong H-Y People's \\
& discussions during the visit & Hospital (Elekta's customer) \\
4 & March 22, 2011/09:30-10:30 & Deputy CEO for Sales and Marketing, Elekta (China) \\
5 & February 13, 2013/16:00-16:45 & Executive Vice President APAC, Elekta Limited \\
6 & April 25, 2013/15:00-16:00 & Board of Directors, Elekta AB \\
\hline
\end{tabular}

\section{References}

Alvarez SA, Barney JB (2007) Discovery and creation: alternative theories of entrepreneurial action. Strateg Entrep J 1:11-26. doi:10.1002/sej.4

Alvarez SA, Barney JB, Young SL (2010) Debates in entrepreneurship: opportunity formation and implications for the field of entrepreneurship. In: Acs ZJ, Audretsch DB (eds) Handbook of entrepreneurship research. Springer, New York, pp 23-45 
Alvarez SA, Barney JB, Anderson P (2013) Forming and exploiting opportunities: the implications of discovery and creation processes for entrepreneurial and organizational research. Organ Sci 24:301317. doi: 10.1287 /orsc. 1110.0727

Andersson U, Blankenburg Holm D, Johanson M (2006) Opportunities, relational embeddedness and network structure. In: Ghauri PN, Hadjikhani A, Johanson J (eds) Managing opportunity development in business networks, illustrated edition. Palgrave, Macmillan, pp 27-48

Ardichvili A, Cardozo R, Ray S (2003) A theory of entrepreneurial opportunity identification and development. J Bus Ventur 18:105-123. doi:10.1016/S0883-9026(01)00068-4

Blazejewski S (2011) When truth is the daughter of time: longitudinal case studies in international business research. In: Marschan-Piekkari R, Welch C (eds) Rethinking the case study in international business and management research. Edward Elgar, Cheltenham, pp 251-271

Burgelman RA (2011) Bridging history and reductionism: a key role for longitudinal qualitative research. J Int Bus Stud 42:591-601. doi:10.1057/jibs.2011.12

Cattani G (2005) Preadaptation, firm heterogeneity, and technological performance: a study on the evolution of fiber optics, 1970-1995. Organ Sci 16:563-580. doi:10.1287/orsc.1050.0145

Chandra Y, Styles C, Wilkinson I (2009) The recognition of first time international entrepreneurial opportunities: evidence from firms in knowledge-based industries. Int Mark Rev 26:30-61. doi:10.1108/ 02651330910933195

Chetty S, Blankenburg Holm D (2000) Internationalisation of small to medium-sized manufacturing firms: a network approach. Int Bus Rev 9:77-93. doi:10.1016/S0969-5931(99)00030-X

Cook KS, Emerson RM (1978) Power, equity and commitment in exchange networks. Am Sociol Rev 43: 721-739

Coviello NE (2006) The network dynamics of international new ventures. J Int Bus Stud 37:713-731

Crick D, Jones MV (2000) Small high-technology firms and international high-technology markets. J Int Mark 8:63-85. doi:10.1509/jimk.8.2.63.19623

Decker S (2013) The silence of the archives: business history, post-colonialism and archival ethnography. Manag Org Hist 8:155-173. doi:10.1080/17449359.2012.761491

Denrell J, Fang C, Winter SG (2003) The economics of strategic opportunity. Strateg Manag J 24:977-990

Du J, Tian Z, Liu Z, Huang H (1995) Operation experience on Leksell stereotactic system. Chin J Stereot Funct Neurosurg 9:29-30

Dubois A, Gadde L-E (2002) Systematic combining: an abductive approach to case research. J Bus Res 55: $553-560$

Dunning JH (1988) The eclectic paradigm of international production: a restatement and some possible extensions. J Int Bus Stud 19:1-31. doi:10.1057/palgrave.jibs.8490372

Easton G (1995) Methodology and industrial networks. In: Möller K, Wilson DT (eds) Business marketing: an interaction and network perspective. Kluwer Academic Publishers, Boston, pp 411-492

Eckhardt JT, Shane SA (2003) Opportunities and entrepreneurship. J Manag 29:333-349. doi:10.1177/ 014920630302900304

Eisenhardt KM (1989) Building theories from case study research. Acad Manag Rev 14:532-550. doi:10. $2307 / 258557$

Elekta (2014) Annual Report. http:/www.elekta.com/dms/elekta/elekta-assets/Investors/pdf/annual-report2013-14/Elekta-Annual-Report-2013-14.pdf. Accessed 5 Mar 2015

Ellis PD (2011) Social ties and international entrepreneurship: opportunities and constraints affecting firm internationalization. J Int Bus Stud 42:99-127. doi:10.1057/jibs.2010.20

Eriksson K, Majkgård A, Sharma DD (2000) Path dependence and knowledge development in the internationalization process. Manag Int Rev 40:307-328

Farjoun M (2002) The dialectics of institutional development in emerging and turbulent fields: the history of pricing conventions in the on-line database industry. Acad Manag J 45:848-874. doi:10.2307/3069318

Hilmersson M, Jansson H (2012) International network extension processes to institutionally different markets: entry nodes and processes of exporting SMEs. Int Bus Rev 21:682-693. doi:10.1016/j. ibusrev.2011.08.003

Hohenthal J, Johanson J, Johanson M (2003) Market discovery and the international expansion of the firm. Int Bus Rev 12:659-672. doi:10.1016/j.ibusrev.2003.06.001

Hohenthal J, Johanson J, Johanson M (2014) Network knowledge and business-relationship value in the foreign market. Int Bus Rev 23:14-19. doi:10.1016/j.ibusrev.2013.08.002

Johanson M, Kao P (2010) Networks in internationalisation. In: Pla-Barber J, Alegre J (eds) Progress in international business research - reshaping the boundaries of the firm in an era of global interdependence. Emerald Group Publishing, Bingley, pp 119-142 
Johanson M, Strömsten T (2005) Value processes in industrial networks: identifying the creation and realisation of value. managing opportunity development in business networks. Palgrave, Macmillan, Houndmills, Basingstoke, Hampshire and New York, pp 110-124

Johanson J, Vahlne J-E (1977) The internationalization process of the firm-a model of knowledge development and increasing foreign market commitments. J Int Bus Stud 8:23-32. doi:10.1057/palgrave.jibs. 8490676

Johanson J, Vahlne J-E (2006) Commitment and opportunity development in the internationalization process: a note on the Uppsala internationalization process model. Manag Int Rev 46:165-178. doi:10.1007/ s11575-006-0043-4

Johanson J, Vahlne J-E (2009) The Uppsala internationalization process model revisited: from liability of foreignness to liability of outsidership. J Int Bus Stud 40:1411-1431. doi:10.1057/jibs.2009.24

Jones G, Khanna T (2006) Bringing history (back) into international business. J Int Bus Stud 37:453-468. doi: 10.1057 palgrave.jibs. 8400198

King N (2004) Using templates in the thematic analysis of text. In: Cassell C, Symon G (eds) Essential guide to qualitative methods in organizational research. Sage Publications Ltd, London, pp 257-270

Kipping M, Wadhwani RD, Bucheli M (2014) Analyzing and interpreting historical sources: a basic methodology. In: Bucheli M, Wadhwani RD (eds) Organizations in time. history, theory, methods. Oxford University Press, Oxford, pp 305-329

Kirzner IM (1997) entrepreneurial discovery and the competitive market process: an Austrian approach. J Econ Lit 35:60-85. doi:10.2307/2729693

Knight GA, Cavusgil ST (2004) Innovation, organizational capabilities, and the born-global firm. J Int Bus Stud 35:124-141

Kontinen T, Ojala A (2011) International opportunity recognition among small and medium-sized family firms. J Small Bus Manag 49:490-514. doi:10.1111/j.1540-627X.2011.00326.x

SP Lab (2011) Mr. Song, Shipeng and Gamma Knife. http://www.splab.com.cn/en/about1.asp. Accessed 25 Nov 2011

Langley A (1999) Strategies for theorizing from process data. Acad Manag Rev 24:691-710

Levie J, Autio E (2011) Regulatory burden, rule of law, and entry of strategic entrepreneurs: an international panel study. J Manag Stud 48:1392-1419. doi:10.1111/j.1467-6486.2010.01006.x

Levin S (2006) Elekta: growing from the head down. In Vivo. http://sis.windhover.com/buy/abstract.php?id= 2006800090\&type $=$ hitlist\&num=68. Accessed 30 Aug 2011

Madhok A (1997) Cost, value and foreign market entry mode: the transaction and the firm. Strateg Manag J 18:39-61

Mainela T, Puhakka V, Servais P (2014) The concept of international opportunity in international entrepreneurship: a review and a research agenda: the concept of international opportunity. Int J Manag Rev 16: 105-129. doi:10.1111/ijmr.12011

Mattsson L-G, Johanson J (1992) Network positions and strategic action: an analytical framework. Reprint Series-Företagsekonomiska institutionen vid Uppsala Universitet

McDougall PP, Shane S, Oviatt BM (1994) Explaining the formation of international new ventures: the limits of theories from international business research. J Bus Ventur 9:469-487. doi:10.1016/0883-9026(94) 90017-5

Meng Z (1990) Applying Leksell stereotactic system to treat Parkinson disease. Chin J Stereot Funct Neurosurg 3:5

Outlook Weekly (2009) The Ups and Downs of the Chinese Gamma Knife. http://w.xinhuanet.com/htm/ content_4833.htm. Accessed 25 Nov 2011

Mintzberg $\bar{H}$ (1977) Strategy formulation as a historical process. Int Stud Manag Org 7:28-40

Pettigrew AM (1990) Longitudinal field research on change: theory and practice. Organ Sci 1:267-292. doi: 10.1287/orsc. 1.3.267

Pettigrew AM, Woodman RW, Cameron KS (2001) Studying organizational change and development: challenges for future research. Acad Manag J 44:697-713. doi:10.2307/3069411

Piekkari R, Welch C (2011) Pluralism in international business and international management research: making the case. In: Piekkari R, Welch $\mathrm{C}$ (eds) Rethinking the case study in international business and management research. Edward Elgar, Cheltenham, pp 3-23

Piekkari R, Plakoyiannaki E, Welch C (2010) "Good" case research in industrial marketing: insights from research practice. Ind Mark Manag 39:109-117. doi:10.1016/j.indmarman.2008.04.017

Pierson P (2000) Increasing returns, path dependence, and the study of politics. Am Polit Sci Rev 94:251-267. doi: $10.2307 / 2586011$

Reid SD (1981) The decision-maker and export entry and expansion. J Int Bus Stud 12:101-112 
Rowlinson M, Hassard J, Decker S (2014) Research strategies for organizational history: a dialogue between historical theory and organization theory. Acad Manag Rev 39:250-274. doi:10.5465/amr.2012.0203

Santangelo GD, Meyer KE (2011) Extending the internationalization process model: increases and decreases of MNE commitment in emerging economies. J Int Bus Stud 42:894-909. doi:10.1057/jibs.2011.25

Schreyögg G, Sydow J (2011) Organizational path dependence: a process view. Organ Stud 32:321-335. doi: $10.1177 / 0170840610397481$

Schreyögg G, Sydow J, Holtmann P (2011) How history matters in organisations: the case of path dependence. Manag Org Hist 6:81-100. doi:10.1177/1744935910387030

Schumpeter JA (1934) The theory of economic development: an inquiry into profits, capital, credit, interest, and the business cycle. Harvard, Cambridge

Schweizer R, Vahlne J-E, Johanson J (2010) Internationalization as an entrepreneurial process. J Int Entrep 8: 343-370. doi:10.1007/s10843-010-0064-8

Shane S (2000) Prior knowledge and the discovery of entrepreneurial opportunities. Organ Sci 11:448-469

Shane S (2003) A general theory of entrepreneurship. Edward Elgar, Cheltenham

Sharma DD, Blomstermo A (2003) The internationalization process of Born Globals: a network view. Int Bus Rev 12:739-753. doi:10.1016/j.ibusrev.2003.05.002

South China Morning Post (1994) Elekta Sees Market for Equipment. South China Morning Post 5. http:// global.factiva.com.ezproxy.its.uu.se/ha/default.aspx. Accessed 24 Apr 2011

Tan H, Nojonen M (2011) Doing case studies in China: two perspectives. In: Piekkari R, Welch C (eds) Rethinking the case study in international business and management research. Edward Elgar, Cheltenham, pp $474-498$

Welch C (2000) The archaeology of business networks: the use of archival records in case study research. J Strateg Mark 8:197-208. doi:10.1080/096525400346259

Welch C, Paavilainen-Mäntymäki E (2014) Putting process (back) in: research on the internationalization process of the firm. Int J Manag Rev 16:2-23. doi:10.1111/ijmr.12006

Wiedersheim-Paul F, Olson HC, Welch LS (1978) Pre-export activity: the first step in internationalization. J Int Bus Stud 9:47-58. doi:10.1057/palgrave.jibs.8490650

Wu C-Y, Wang Y-H, Meng F-G, Liu Y-G (2005) Development of Stereotactic Neurosurgery in China. Neurosurgery 56:851-860. doi:10.1227/01.NEU.0000156618.10291.F2

Xu J (1990) Twenty five year of development on stereotactic and functional neurosurgery in China. Chin J Stereot Funct Neurosurg 3:3-5

Xu J, Wang Y, Xu F, Shao K (1978) Conclusion of 100 clinic trials of the stereotactic system. Med Equip 6:78

Yin RK (2003) Case study research: design and methods, 3rd edn. Sage Publications Inc, Thousand Oaks

Zander I (2007) Do you see what I mean? An entrepreneurship perspective on the nature and boundaries of the firm. J Manag Stud 44:1141-1164. doi:10.1111/j.1467-6486.2007.00732.x

Zhang Z (2009) Development in radiotherapy devices of China-Development of accelerator in medicine in recent 30 years. China Medical Equipment 6:1-8 